\title{
Good Genes from Asia-Contributions and Opportunities of Asian Origin Crops to U.S. Horticulture: An Introduction to the Workshop
}

\author{
Yan Chen ${ }^{1}$ \\ Louisiana State University Agricultural Center Hammond Research Station, 21549 Old Covington Highway, \\ Hammond, LA 70403 \\ Jayesh B. Samtani \\ Department of Horticulture, Hampton Roads AREC, Virginia Polytechnic Institute and State University, \\ 1444 Diamond Springs Road, Virginia Beach, VA 23455-3315
}

Asia is a region rich in plant biodiversity with many centers of origin for numerous horticultural crops. Plant germplasm from Asia is thus important for new crop development in North America. Globalization and increased immigration have opened up markets for many Asian horticultural crops that are not currently or widely cultivated in the United States or have not been included in past germplasm exchanges. Many of them have the potential to become niche market crops, increasing crop diversity and the economic sustainability for American farmers as well as benefiting consumers because of unique nutritional or medicinal values.

In the past, several workshops have discussed use of indigenous Asian plants (Mou and Wang, 2012), plant exploration in Asia (Hummer, 2007; Volk and Richards, 2011), and germplasm exchange experiences with countries signed up for the Convention on Biological Diversity (Widrlechner, 2005). Some of these workshops were hosted by the Working Group of Asian Horticulture. As the group began planning for the 2012 workshop, the idea of reviewing and introducing interesting ornamental plants into U.S. landscapes was brought up at the working group business meeting in Waikoloa, HI. This was further developed into a colloquium proposal by expanding to pomology and vegetable crops. Five speakers, including one international speaker, renowned for their experiences in germplasm collection and introduction, were invited. Although we did not secure the colloquium, the speakers decided to contribute to this topic as a workshop, and the allocated time for the workshop was extended to accommodate the rich content it offered to the audience.

The workshop location could not have been any more appropriate than Miami, FL, a state very rich in both indigenous and introduced plant germplasm, with many species introduced from Asia. The objectives of this workshop were to 1) review contributions of Asian germplasm to the development of important horticultural crops, including small berries, woody ornamentals, and vegetables; 2) discuss regulatory issues and other barriers that exist in using Asian germplasm resources; and 3) provide outlooks for future opportunities in introducing new crops with Asian germplasm.

Dr. Richard Olsen, from the U.S. National Arboretum, Floral \& Nursery Plants Research Unit in Washington, DC, presented the latest information on germplasm resources of Asian origin for woody ornamentals and current germplasm exchange climate and regulatory issues between Asian countries and the United States under the influence of the Convention on Biological Diversity and U.S. import regulations.

Dr. James D. McCreight, from USDAARS, U.S. Agricultural Research Station in Salinas, CA, reviewed a wide range of valuable traits of melons and several other cucurbits that have been introduced or could be introduced to the United States as well as two important horticultural technologies that originated in Asia.
Dr. Kim Hummer, from USDA-ARS, National Clonal Germplasm Repository in Corvallis, OR, discussed the evolution of the octoploid strawberry species, Asian genes and breeding traits of raspberry, and described several berry species indigenous to Asia that could be used to develop new berry crops in the United States.

From the content discussed in the workshop, it was evident that Asian germplasm has enormous potential for North American horticulture. Although germplasm exchange activities have been affected by changes in international laws and national regulations, the contribution of Asian germplasm to U.S. horticulture will increase as researchers continue to use its rich gene pools to develop cultivars with superior qualities.

\section{Literature Cited}

Hummer, K. 2007. Introduction (for workshop "Plant Exploration for New Fruits"). HortScience 42:190.

Mou, B. and G. Wang. 2012. Asia's indigenous horticultural crops: An introduction (for workshop "Asia's indigenous horticultural crops"). HortScience 47:819-820.

Volk, G.M. and C.M. Richards. 2011. Horticultural value of wild genetic resourcesIntroduction to the workshop. HortScience 46:1436-1437.

Widrlechner, M.P. 2005. Introduction to the workshop (for workshop "Germplasm Acquisition from Conception to Products"). HortScience 40:296.

\footnotetext{
Received for publication 11 Mar. 2013. Accepted for publication 28 Mar. 2013.

This paper was part of the workshop "Good Genes from Asia-Contributions and Opportunities of Asiatic Origin Crops to U.S. Horticulture" held 3rd Aug. 2012 at the ASHS Conference, Miami, FL, and sponsored by the Working Group of Asian Horticulture and The Association of Horticulturists of Indian Origin.

${ }^{1}$ To whom reprint requests should be addressed; e-mail yachen@agcenter.lsu.edu.
} 